Retrieving Experience 



\section{Retrieving Experience}

Subjectivity and Recognition

in Feminist Politics

Sonia Kruks

CORNELL UNIVERSITY PRESS

ITHACA AND LONDON 


\section{Copyright $(\odot 200$ I by Cornell University}

All rights reserved. Except for brief quotations in a review, this book, or parts thereof, must not be reproduced in any form without permission in writing from the publisher. For information, address Cornell University Press, Sage House, 5 I 2 East State Street, Ithaca, New York I4850.

First published 200 I by Cornell University Press

First printing, Cornell Paperbacks, $200 \mathrm{I}$

Printed in the United States of America

\section{Library of Congress Cataloging-in-Publication Data}

Kruks, Sonia.

Retrieving experience : subjectivity and recognition in feminist politics / Sonia Kruks.

p. $\mathrm{cm}$.

Includes bibliographical references and index.

ISBN 0-8014-3387-8 (cloth : alk. paper) -

ISBN 0-8014-8417-0 (pbk. : alk. paper)

1. Feminist theory. 2. Existential phenomenology.

3. Subjectivity. 4. Postmodernism. I. Title.

HQ1190.K78 2001

$305.42^{\prime} 01-\mathrm{dc} 21$

00-010474

Cornell University Press strives to use environmentally responsible suppliers and materials to the fullest extent possible in the publishing of its books. Such materials include vegetable-based, low-VOC inks and acid-free papers that are recycled, totally chlorine-free, or partly composed of nonwood fibers. Books that bear the logo of the FSC (Forest Stewardship Council) use paper taken from forests that have been inspected and certified as meeting the highest standards for environmental and social responsibility. For further information, visit our website at www.cornellpress.cornell.edu.

Cloth printing

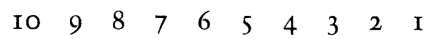

$\begin{array}{lllllllllll}\text { Paperback printing } & \text { IO } & 9 & 8 & 7 & 6 & 5 & 4 & 3 & 2 & \text { I }\end{array}$ 
For Ben and Gabi-

and in loving memory of Gabe, who died too soon 

It was a desire, a sound; she could drape it in colours, see it in form, hear it in music, but not in words; no, never in words. She sighed, teased by desires so incoherent, so incommunicable.

$$
\begin{aligned}
& \text {-Virginia Woolf, } \\
& \text { Night and Day }
\end{aligned}
$$

There is no liberation that only knows how to say " $\mathrm{I}$ "; there is no coalition movement that speaks for each of us all the way through.

-Adrienne Rich,

"Notes toward a Politics of Location" 
